\title{
Electrochemical behaviour of isatin at a glassy carbon electrode
}

\author{
Victor C. Diculescu ${ }^{\mathrm{a}}$, Sunita Kumbhat ${ }^{\mathrm{b}}$, Ana Maria Oliveira-Brett ${ }^{\mathrm{a}, *}$ \\ a Departamento de Química, Faculdade de Ciências e Tecnologia, Universidade de Coimbra, 3004-535 Coimbra, Portugal \\ ${ }^{\mathrm{b}}$ Electroanalytical and Environmental Laboratory, Department of Chemistry, J.N.V. University, Jodhpur 342001, India
}

Received 8 March 2006; received in revised form 24 May 2006; accepted 26 May 2006

Available online 3 June 2006

\begin{abstract}
The electrochemical behavior of isatin - a molecule with a broad range of applications in synthetic, biological and clinical activity - has been investigated over a wide $\mathrm{pH}$ range at a glassy carbon electrode (GCE) using cyclic, square wave and differential pulse voltammetry. The oxidation of isatin is an irreversible process, $\mathrm{pH}$ dependent and occurs with the formation of a main oxidation product that strongly adsorbs on the electrode surface. The reduction of isatin is also a pH dependent irreversible process. Cyclic voltammograms show two consecutive charge transfer reactions. The diffusion coefficient of isatin was calculated in $\mathrm{pH} 7.0$ phosphate buffer to be $D_{0}=4.9 \times 10^{-7} \mathrm{~cm}^{2} \mathrm{~s}^{-1}$. The limit of detection obtained in a solution of $\mathrm{pH} 7.0$ phosphate buffer was $\mathrm{LOD}=0.194 \mu \mathrm{M}$, based on three times the noise level.
\end{abstract}

(c) 2006 Elsevier B.V. All rights reserved.

Keywords: Isatin; Indole; Oxidation; Reduction; Voltammetry

\section{Introduction}

The indole is a powerful pharmacodynamic nucleus and has been reported to possess a wide variety of important biological properties such as anti-inflammatory, antibacterial, anticonvulsant and antioxidant properties [1-3].

Among the indoles, isatin (indole-2,3-dione) (Scheme 1), a versatile heterocyclic compound present in mammalian tissues and body fluids [4,5], is probably one of the most important. The function of isatin as a modulator of different biochemical processes has been a subject of discussion during the past decade. This substance was initially discovered as an inhibitor of monoamine oxidase (MAO), and subsequently identified as a selective inhibitor of MAO B [4,6]. Further investigations have shown that isatin acts as an antagonist of both atrial natriuretic peptide-stimulated [7] and nitric oxide-stimulated [8] guanylate cyclase activity. Isatin has a distinct and discontinuous distribution in brain and other tissues; the highest concentrations $\left(0.1 \mu \mathrm{gg}^{-1}\right.$ or about $\left.1 \mu \mathrm{M}\right)$ in the brain are found in the hippocampus and cerebellum $[9,10]$.

In rat models, stress has been shown to cause an increase of isatin levels in the brain, heart, blood plasma and also

\footnotetext{
* Corresponding author. Tel.: +351 239 835295; fax: +351 239835295 .

E-mail address: brett@ ci.uc.pt (A.M. Oliveira-Brett).
}

increased urinary output of isatin. In vivo isatin administration causes a range of dose-dependent behavioral effects, including anxiety at low doses $\left(10-20 \mathrm{mg} \mathrm{kg}^{-1}\right)$ and sedation at higher doses (80-200 $\left.\mathrm{mg} \mathrm{kg}^{-1}\right)$ [10-12]. This suggests that different biochemical mechanisms are involved in these diverse effects. However, the functional significance of isatin in the physiology of stress is not yet clearly established.

On the other hand, pathways for the synthesis and metabolism of isatin in animal tissues have not been fully recognized. It has been suggested that isatin is formed in tissues from phenylalanine or tryptophan [7,13]. In vitro, isatin can be destroyed easily by a high concentration of hydrogen peroxide. Moreover, isatin is readily metabolized by xanthine oxidase, producing hydrogen peroxide via the formation of superoxide $[7,14$ and references therein]. However, at this stage it is unclear whether this mechanism operates also in vivo.

In recent years, the chemistry of indoles has received a lot of attention due to their wide application for analytical and synthetic purposes. The synthetic versatility of isatin has stemmed from the interest in the biological and pharmacological properties of its derivatives [15]. Although the presence of two carbonyl groups in isatin makes it an attractive target to synthetic organic chemists, little is known about its redox mechanism. Previous studies on the electrochemical reduction behavior of isatin and analog compounds have been undertaken using polarography at mercury electrodes [16-19]. Although 


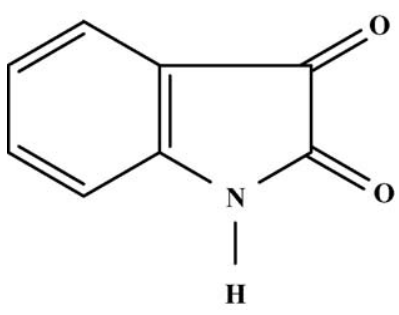

Scheme 1. Chemical structure of isatin.

some investigations concerning the oxidation behavior of isatin have been recently carried out at platinum, gold and glassy carbon electrodes, more work has to be done to fully characterize the isatin redox mechanism.

Investigations of the redox behavior of biologically occurring compounds by means of electrochemical techniques have the potential for providing valuable insights into the biological redox reactions of these molecules. Due to their high sensitivity, voltammetric methods have been successfully used to study the redox behavior of various biological compounds [20-23]. The present study is concerned with probing the redox properties of isatin by using cyclic, square wave and differential pulse voltammetry at a glassy carbon electrode.

\section{Experimental}

\subsection{Materials and reagents}

Isatin from Loba-Chemie Indoaustranal Co. (India) was used without further purification. A stock solution of $1 \mathrm{mM}$ isatin was prepared in deionized water and was stored at $-4{ }^{\circ} \mathrm{C}$.

All supporting electrolyte solutions (Table 1) were prepared using analytical grade reagents and purified water from a Millipore Milli-Q system (conductivity $\leq 0.1 \mu \mathrm{S} \mathrm{cm}^{-1}$ ).

Nitrogen saturated solutions were obtained by bubbling high purity $\mathrm{N}_{2}$ for a minimum of $10 \mathrm{~min}$ in the solution and continuing with a flow of pure gas over the solution during the voltammetric experiments.

Microvolumes were measured using EP-10 and EP-100 Plus Motorized Microliter Pippettes (Rainin Instrument Co. Inc., Woburn, USA). The $\mathrm{pH}$ measurements were carried out with a Crison micropH $2001 \mathrm{pH}$-meter with an Ingold combined

Table 1

Supporting electrolytes, $0.2 \mathrm{M}$ ionic strength

\begin{tabular}{rl}
\hline $\mathrm{pH}$ & Composition \\
\hline 1.2 & $\mathrm{HCl}+\mathrm{KCl}$ \\
2.2 & $\mathrm{HCl}+\mathrm{KCl}$ \\
3.4 & $\mathrm{HAcO}+\mathrm{NaAcO}$ \\
4.5 & $\mathrm{HAcO}+\mathrm{NaAcO}$ \\
5.3 & $\mathrm{HAcO}+\mathrm{NaAcO}$ \\
6.1 & $\mathrm{NaH}_{2} \mathrm{PO}_{4}+\mathrm{Na}_{2} \mathrm{HPO}_{4}$ \\
7.0 & $\mathrm{NaH}_{2} \mathrm{PO}_{4}+\mathrm{Na}_{2} \mathrm{HPO}_{4}$ \\
8.1 & $\mathrm{NaH}_{2} \mathrm{PO}_{4}+\mathrm{Na}_{2} \mathrm{HPO}_{4}$ \\
9.3 & $\mathrm{NaOH}_{2} \mathrm{Na}_{2} \mathrm{~B}_{2} \mathrm{O}_{7}$ \\
11.1 & $\mathrm{NaOH}+\mathrm{KCl}$ \\
12.8 & $\mathrm{NaOH}+\mathrm{KCl}$ \\
\hline
\end{tabular}

glass electrode. All experiments were done at room temperature $\left(25 \pm 1^{\circ} \mathrm{C}\right)$.

\subsection{Voltammetric parameters and electrochemical cells}

Voltammetric experiments were carried out using a $\mu$ Autolab running with GPES 4.9 software, Eco-Chemie, Utrecht, The Netherlands. Measurements were carried out using a glassy carbon (GCE) $(d=1.5 \mathrm{~mm})$ working electrode, a Pt wire counter electrode, and a $\mathrm{Ag} / \mathrm{AgCl}(3 \mathrm{M} \mathrm{KCl})$ as reference, in a $0.5 \mathrm{~mL}$ one-compartment electrochemical cell. The experimental conditions for differential pulse voltammetry (DPV) were: pulse amplitude $50 \mathrm{mV}$, pulse width $70 \mathrm{~ms}$, scan rate $5 \mathrm{mV} \mathrm{s}^{-1}$.

The GCE was polished using diamond spray (particle size $1 \mu \mathrm{m}$ ) before each experiment. After polishing, the electrode was rinsed thoroughly with Milli-Q water for $30 \mathrm{~s}$; then it was sonicated for $1 \mathrm{~min}$ in an ultrasound bath and again rinsed with water. After this mechanical treatment, the GCE was placed in $\mathrm{pH} 7.00 .2 \mathrm{M}$ phosphate buffer electrolyte and various DP voltammograms were recorded until a steady state baseline voltammogram was obtained. This procedure ensured very reproducible experimental results.

\subsection{Acquisition and presentation of voltammetric data}

All the voltammograms presented were backgroundsubtracted and baseline-corrected using the moving average with a step window of $5 \mathrm{mV}$ included in GPES Version 4.9 software. This mathematical treatment improves the visualization and identification of peaks over the baseline without introducing any artifact, although the peak height is in some cases reduced $(<10 \%)$ relative to that of the untreated curve. Nevertheless, this mathematical treatment of the original voltammograms was used in the presentation of all experimental voltammograms for a better and clearer identification of the peaks. The values for peak current presented in all graphs were determined from the original untreated voltammograms after subtraction of the baseline.

\section{Results and discussion}

Initial studies concerning the voltammetric behavior of isatin at a GCE were carried out in $\mathrm{pH} 7.00 .2 \mathrm{M}$ phosphate buffer. The cyclic voltammogram in Fig. 1 was obtained in a solution of $330 \mu \mathrm{M}$ isatin saturated with $\mathrm{N}_{2}$. During the voltammetric measurement a constant flux of $\mathrm{N}_{2}$ was kept over the solution surface in order to avoid the diffusion of atmospheric oxygen into the solution of isatin.

Several peaks can be observed in Fig. 1. The reduction and oxidation of isatin occur independently of each other and were investigated separately.

\subsection{Oxidation}

\subsubsection{Cyclic voltammetry}

The oxidation of isatin at a GCE was studied by cyclic voltammetry (CV) in pH 7.0 0.2 M phosphate buffer. The CV obtained in a $330 \mu \mathrm{M}$ isatin solution at a scan rate $\nu=50 \mathrm{mV} \mathrm{s}^{-1}$ (Fig. 2) 


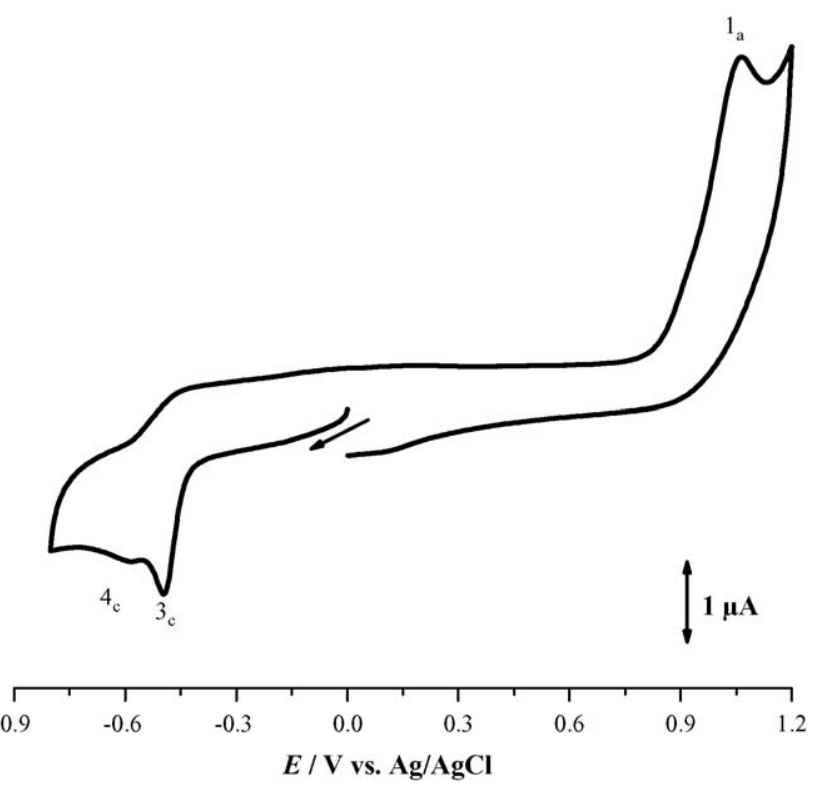

Fig. 1. Cyclic voltammogram obtained in, $\mathrm{N}_{2}$ saturated, $330 \mu \mathrm{M}$ isatin in $\mathrm{pH}$ 7.0 0.2 $\mathrm{M}$ phosphate buffer solution, $v=100 \mathrm{mV} \mathrm{s}^{-1}$.

shows one anodic peak $1_{\mathrm{a}}$ that occur at $E_{\mathrm{pa}}=+1.08 \mathrm{~V}$. On scanning in the negative direction, no reduction peak is observed, showing that the oxidation of isatin is an irreversible process. A decrease of the oxidation current occurs with the number of successive scans and is due to the adsorption of isatin oxidation products on the GCE surface.

$\mathrm{CVs}$ were also obtained for different scan rates in $330 \mu \mathrm{M}$ isatin in $\mathrm{pH} 7.00 .2 \mathrm{M}$ phosphate buffer. By increasing the scan rate, the peak $1_{\mathrm{a}}$ current increases, following a linear relationship with scan rate. This can be explained taking into consideration the adsorption of isatin molecules and/or their oxidation products at the GCE surface. Such a kind of behavior was already described for substances similar to isatin molecule such that indole-3-acetic acid [24,25].

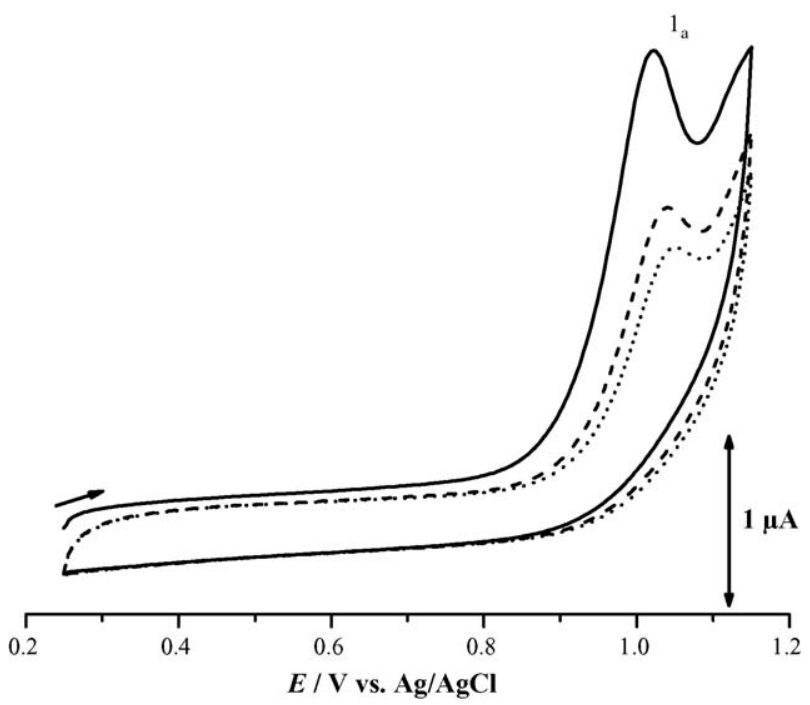

Fig. 2. Cyclic voltammogram obtained in $330 \mu \mathrm{M}$ isatin in $\mathrm{pH} 7.00 .2 \mathrm{M}$ phosphate buffer solution: (-) first, (--) second and ( ..) third scan at $\nu=50 \mathrm{mV} \mathrm{s}^{-1}$.
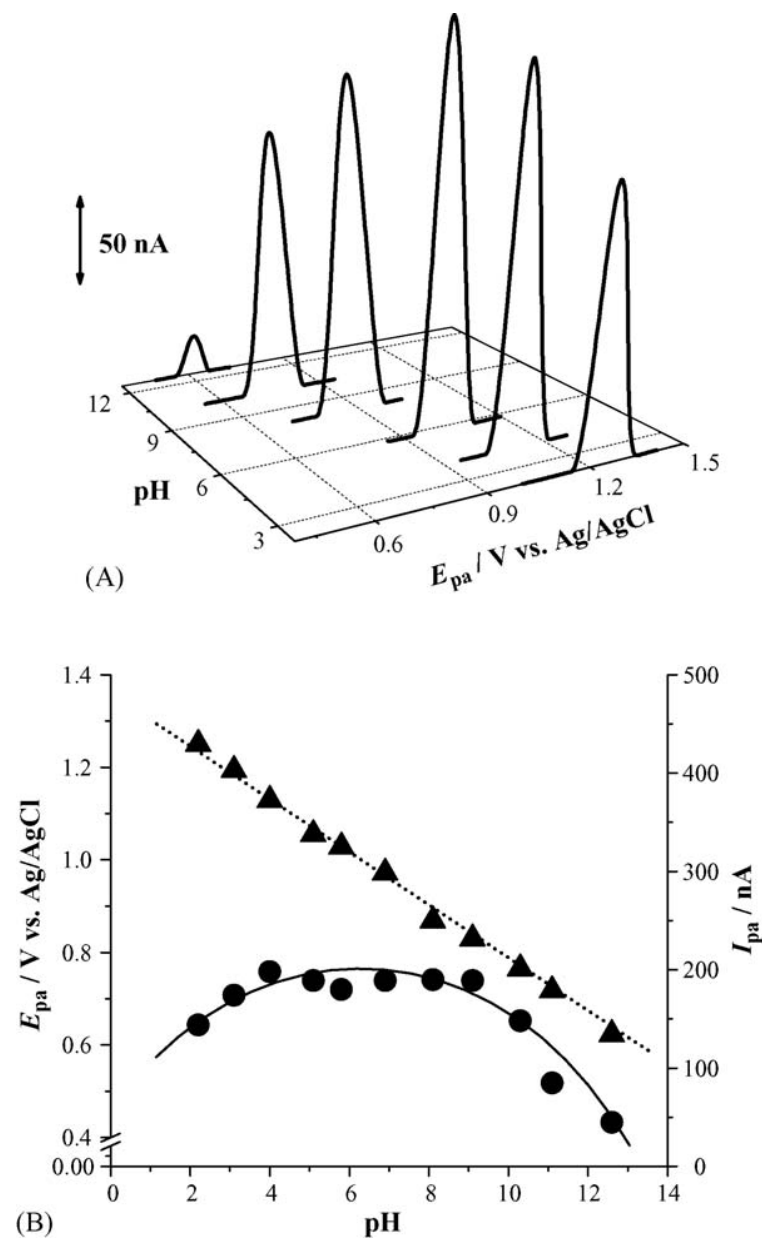

Fig. 3. (A) 3D plot of oxidation DP voltammograms obtained in $50 \mu \mathrm{M}$ isatin as a function of $\mathrm{pH}$. (B) Plot of $(\boldsymbol{\Lambda}) E_{\mathrm{pa}}$ and $(\bullet) I_{\mathrm{pa}}$ of peak $1_{\mathrm{a}}$ vs. $\mathrm{pH}$.

\subsubsection{Differential pulse voltammetry}

The electrochemical oxidation of isatin was studied over a wide $\mathrm{pH}$ range between 2 and 13 using differential pulse (DP) voltammetry. The DP voltammograms (Fig. 3A) were all recorded in solutions of $50 \mu \mathrm{M}$ isatin in different electrolytes with $0.2 \mathrm{M}$ ionic strength. One main oxidation peak $1_{\mathrm{a}}$ appears in all electrolytes and the potential depends on $\mathrm{pH}$.

The peak $1_{\mathrm{a}}$ potential is displaced to more negative values with increasing $\mathrm{pH}$. The dependence is linear over the whole $\mathrm{pH}$ range and follows the relationship $E_{\mathrm{pa}}(\mathrm{V})=1.38-0.061 \mathrm{pH}$ (Fig. 3B). The slope of the line, $61 \mathrm{mV}$ per $\mathrm{pH}$ unit, shows that the oxidation mechanism of isatin involves the same number of electrons and protons. However, in all electrolytes, the width at half-height of isatin oxidation peak $1_{\mathrm{a}}$ was $W_{1 / 2}=93 \mathrm{mV}$, meaning that the oxidation process of isatin involves the transfer of one electron and one proton.

The plot of the variation of peak $1_{\mathrm{a}}$ current versus $\mathrm{pH}$ (Fig. 3B) shows that the current increases with $\mathrm{pH}$, reaching a maximum in $\mathrm{pH}$ 7.0 0.2 M phosphate buffer, and this electrolyte was used for further studies.

Successive DP voltammograms were recorded in a solution of $50 \mu \mathrm{M}$ isatin in pH 7.0 0.2 M phosphate buffer (Fig. 4A). The oxidation of isatin, peak $1_{\mathrm{a}}$, occurs at $E_{\mathrm{pa}}=+0.95 \mathrm{~V}$. During 

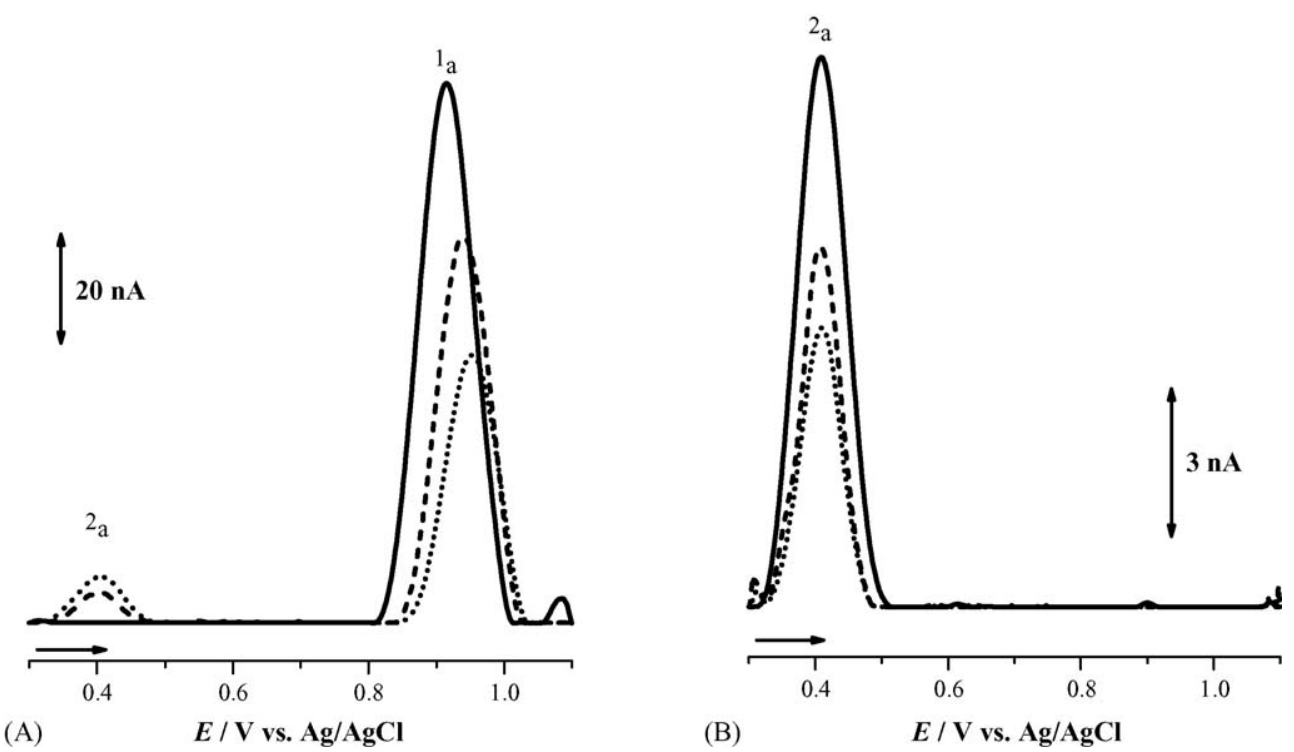

Fig. 4. Successive DP voltammograms: (-) first, (-- ) second and ( . .) third scan, in pH 7.0 $0.2 \mathrm{M}$ phosphate buffer; (A) $50 \mu \mathrm{M}$ isatin and (B) after the transfer of the GCE from the solution containing isatin to buffer.

a second DP scan, a new peak 2 a occurs at $E_{\mathrm{pa}}=+0.42 \mathrm{~V}$, and its amplitude increases with the number of scans. This peak corresponds to the oxidation of the product of oxidation of isatin, $P_{\text {isatin }}$, which is strongly adsorbed on the electrode surface. At the same time, the oxidation current of isatin decreases gradually with the number of scans due to the decrease of the available electrode surface area because of the adsorption of isatin's oxidation product, $P_{\text {isatin }}$.

The adsorption of $P_{\text {isatin }}$ at the GCE surface was confirmed when, after several DP scans recorded in the solution of isatin, the electrode was washed with a jet of deionized water and then transferred to the supporting electrolyte. The DP voltammogram obtained in these conditions (Fig. 4B) shows only the oxidation of $P_{\text {isatin }}$, peak 2 a. That means isatin does not adsorb at the GCE surface. Moreover, successively recorded DP voltammograms in buffer showed only a continuous, but slow decrease of the peak $2_{\mathrm{a}}$ oxidation current (Fig. 4B).

\subsubsection{Square wave voltammetry}

The advantages of square wave (SW) voltammetry are greater speed of analysis, lower consumption of the electroactive species in relation with DP voltammetry, and reduced problems with the poisoning of the electrode surface. The SW voltammograms obtained in a solution of $50 \mu \mathrm{M}$ isatin in $\mathrm{pH} 7.00 .2 \mathrm{M}$ phosphate buffer, show only isatin oxidation peak $1_{\mathrm{a}}, E_{\mathrm{pa}}=+0.98 \mathrm{~V}$, and no isatin oxidation product peak 2 a could be observed even after several scans successively recorded in the same solution (Fig. 5A).

In order to observe the adsorption of $P_{\text {isatin }}$ at the GCE surface, a clean electrode was immersed in a solution of $50 \mu \mathrm{M}$ isatin in $\mathrm{pH} 7.00 .2 \mathrm{M}$ phosphate buffer, where a potential of $+1.10 \mathrm{~V}$ was applied during $60 \mathrm{~s}$ (Fig. 5B). This conditioning procedure caused the oxidation of isatin molecules that diffuse from the solution toward the electrode surface and the produc- tion of $P_{\text {isatin. }}$. However, $P_{\text {isatin }}$ is also oxidized at $+1.10 \mathrm{~V}$ and the SW voltammogram obtained - not shown - presented only a very small peak $2_{\mathrm{a}}$.

This can be improved when, after the first conditioning stage described above, a second conditioning stage, where a potential of $+0.30 \mathrm{~V}$ is applied for $60 \mathrm{~s}$, is applied. During this period, the $P_{\text {isatin }}$ oxidized during the first conditioning stage is reduced and, the $\mathrm{SW}$ voltammogram obtained shows peak $2_{\mathrm{a}}$ at $E_{\mathrm{pa}}=+0.45 \mathrm{~V}$ (Fig. 5B). The reversibility of peak 2 a is confirmed by plotting the forward and backward components of the total current where the oxidation and the reduction currents are equal. Moreover, the identical value of the potential of peak $2 \mathrm{a}$ on the forward and on the backward current components is also an indication of the adsorption of $P_{\text {isatin }}$ on the GCE surface [26].

The product of the 1-electron and 1-proton oxidation of isatin, on the basis of molecular orbital calculations, leads to the formation of oxo-isatin [27]. The oxo-isatin moiety can also undergo reversible oxidation as demonstrated by SWV studies (Fig. 5). A mechanism for the oxidation of isatin in $\mathrm{pH} 70.2 \mathrm{M}$ phosphate buffer is proposed (Scheme 2) based on the results presented.

\subsection{Reduction}

\subsubsection{Cyclic voltammetry}

The reduction of isatin at a GCE was first studied in $\mathrm{pH} 7.0$ $0.2 \mathrm{M}$ phosphate buffer $\mathrm{N}_{2}$ saturated solutions. Cyclic voltammograms recorded in $330 \mu \mathrm{M}$ isatin for $\nu<300 \mathrm{mV} \mathrm{s}^{-1}$ revealed that the reduction of isatin is an irreversible process that occurs in two steps, peaks $3_{\mathrm{c}}$ and $4_{\mathrm{c}}$ (Fig. 6).

The cathodic peak $3_{\mathrm{c}}, E_{\mathrm{pc}}=-0.48 \mathrm{~V}$, appears to be due to the reduction of the carbonyl group at position 3 of the isatin moiety [16]. On the other hand, it is known that in acidic media, isatin is reduced in a 1-electron step giving rise to a radical that can react with an isatin molecule leading to the formation of the dimer isatide [16]. Therefore, the cathodic peak $4_{\mathrm{c}}$ at $E_{\mathrm{pc}}=-0.59 \mathrm{~V}$ 

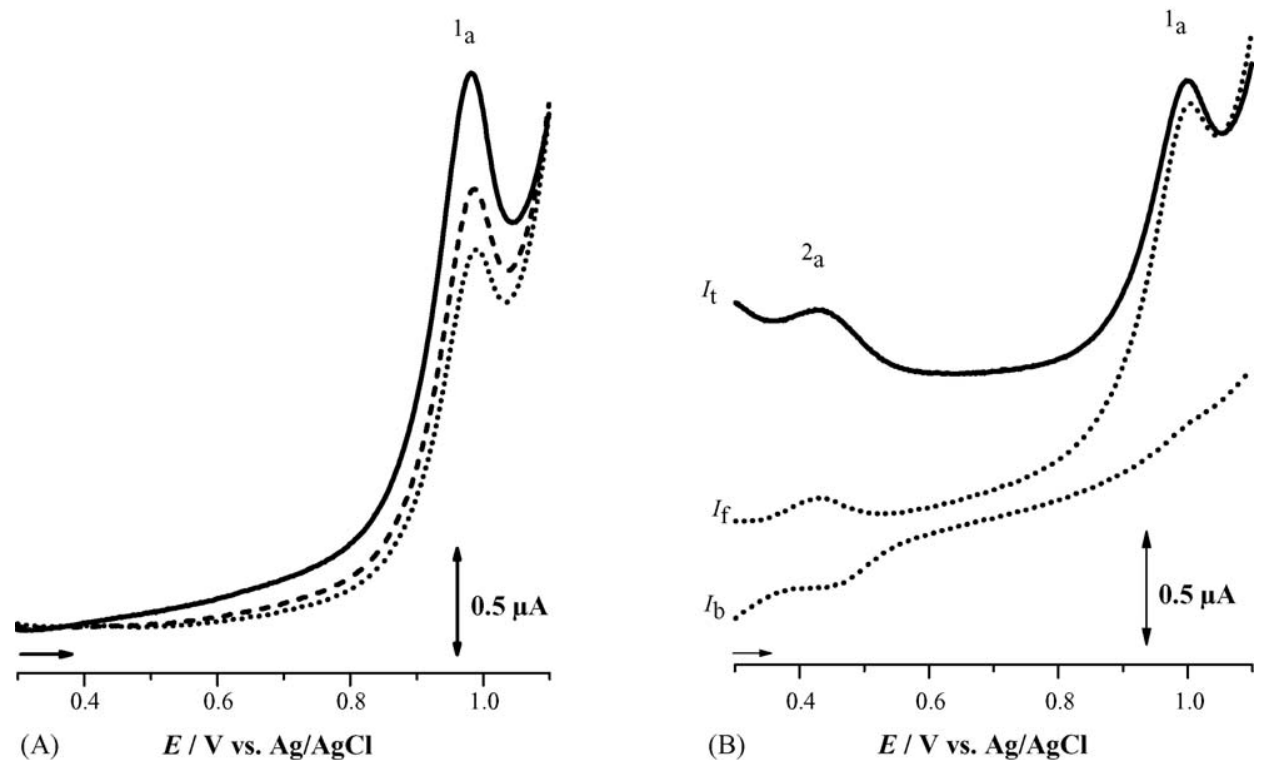

Fig. 5. SW voltammograms recorded in $50 \mu \mathrm{M}$ isatin in $\mathrm{pH} 7.00 .2 \mathrm{M}$ phosphate buffer: (A) without ((-) first, (---) second and (...) third scan), and (B) after, conditioning the GCE in the $50 \mu \mathrm{M}$ isatin in $\mathrm{pH} 7.00 .2 \mathrm{M}$ phosphate buffer for $60 \mathrm{~s}$ at $+1.10 \mathrm{~V}$ followed by application of $+0.30 \mathrm{~V}$ during $60 \mathrm{~s}$ (for more details see Section 3.1.3), $f=50 \mathrm{~Hz}, \Delta E_{\mathrm{s}}=2 \mathrm{mV}$, pulse amplitude $50 \mathrm{mV} ; I_{\mathrm{t}}$ - total current, $I_{\mathrm{f}}$ - forward current, $I_{\mathrm{b}}$ - backward current.

could be due to the reduction of isatide, formed at the electrode surface after reduction of isatin, as shown in the proposed reduction mechanism (Scheme 3). However, scanning in the positive direction, no oxidation peak is observed showing that the reduction of isatin is an irreversible process. Also, no decrease of the cathodic current occurs with successive scans leading to the conclusion that no adsorption of isatin or its reduction product occurs at the GCE surface.

$\mathrm{CVs}$ were also obtained for different scan rates in a $\mathrm{N}_{2}$ saturated solution of $330 \mu \mathrm{M}$ isatin in $\mathrm{pH}$ 7.0 0.2 $\mathrm{M}$ phosphate buffer. From Fig. 6 it was also observed that increasing the scan rate above $300 \mathrm{mV} \mathrm{s}^{-1}$, only peak $3_{\mathrm{c}}$ occurs. The disappearance of peak $4_{c}$ in these conditions could be explained considering that for $v>300 \mathrm{mV} \mathrm{s}^{-1}$, the potential is scanned faster than the rate of the chemical reaction that leads to the formation of the dimer isatide.

On the other hand, by increasing the scan rate, the peak $3 \mathrm{c}$ potential is slightly displaced to more negative values. It is known that for a diffusion-controlled irreversible system, the peak potential is given by

$$
E_{\mathrm{pc}}=E^{\theta^{\prime}}-\frac{R T}{\alpha_{\mathrm{c}} n^{\prime} F}\left[0.780+\ln \frac{D_{0}{ }^{1 / 2}}{k_{0}}+\frac{1}{2} \ln \frac{\alpha_{\mathrm{c}} n^{\prime} F \nu}{R T}\right]
$$

where $\alpha_{\mathrm{c}}$ is the cathodic charge transfer coefficient, $n^{\prime}$ the number of electrons in the rate-determining step, $D_{0}$ the diffusion coefficient and $k_{0}$ is the standard rate constant of the electrochemical reaction [28]. From this equation it can be concluded that $\left|\mathrm{d} E_{\mathrm{p}} / \mathrm{d} \ln \nu\right|=-29.6 /\left(\alpha_{\mathrm{c}} n^{\prime}\right)$. In case of isatin, the dependence of peak potential is linear with $\log$ of the scan rate with a slope of $-21 \mathrm{mV}$ decade $^{-1}$, allowing the calculation of $\alpha_{\mathrm{c}} n^{\prime}=1.4$.

Also, increasing the scan rate the cathodic current of peak $3_{\mathrm{c}}$ increases following a linear relationship with $v^{1 / 2}$. The peak current for a diffusion-controlled irreversible system is given by $I_{\mathrm{pc}}(\mathrm{A})=-2.99 \times 10^{5} n\left(\alpha_{\mathrm{c}} n^{\prime}\right)^{1 / 2} A[\mathrm{O}]_{\infty} D_{0}{ }^{1 / 2} v^{1 / 2}$ where $A$ is the

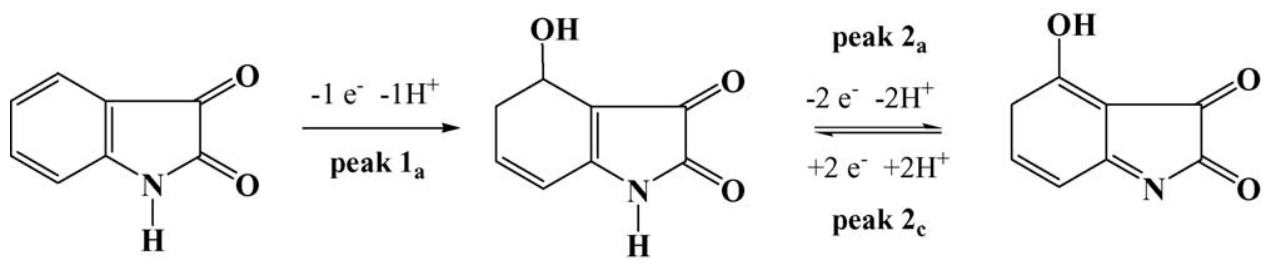

Scheme 2. Proposed oxidation mechanism of isatin in $\mathrm{pH} 70.2 \mathrm{M}$ phosphate buffer.<smiles>O=C1Nc2ccccc2C1=O</smiles>

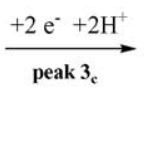<smiles>O=C1Nc2ccccc2C1O</smiles><smiles>[InH][IH-]</smiles><smiles>O=C1Nc2ccccc2C1(O)C1(O)C(=O)N(I)c2ccccc21</smiles>

Scheme 3. Proposed reduction mechanism of isatin in $\mathrm{pH} 70.2 \mathrm{M}$ phosphate buffer. 


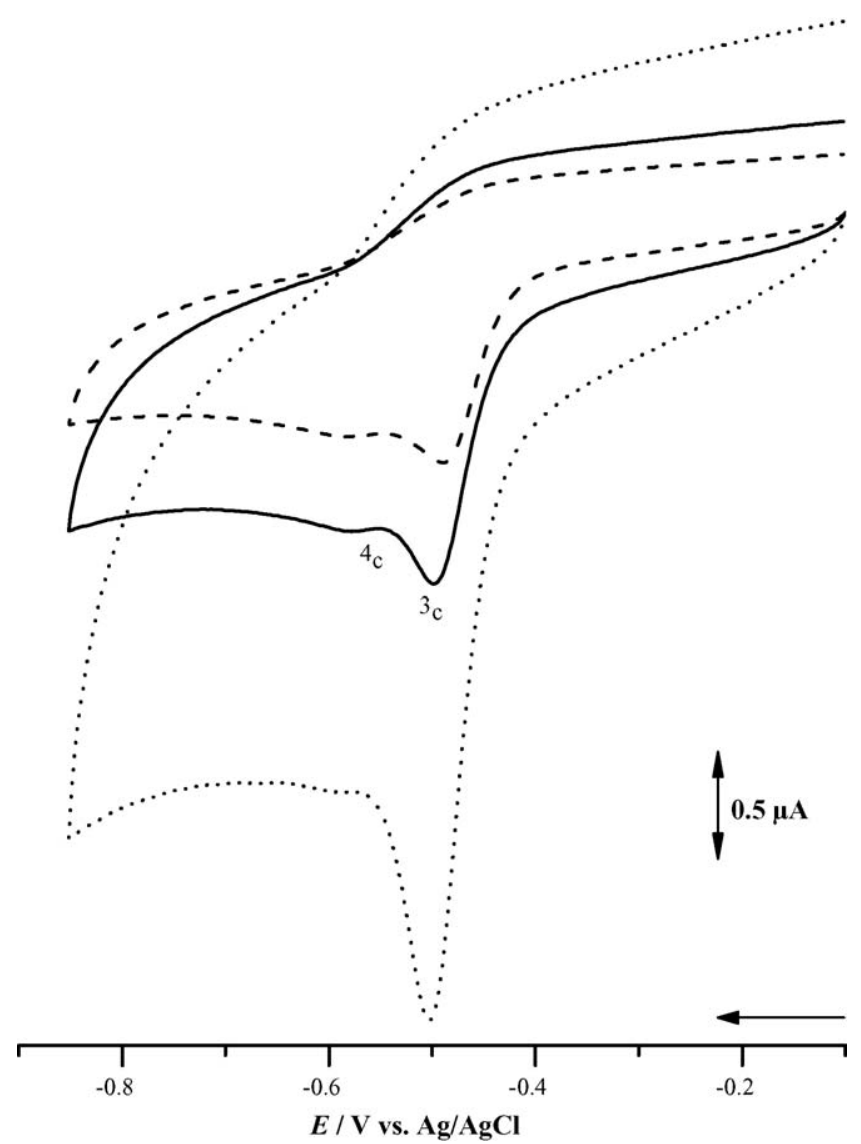

Fig. 6. Cyclic voltammogram obtained in, $\mathrm{N}_{2}$ saturated, $330 \mu \mathrm{M}$ isatin in $\mathrm{pH}$ 7.0 0.2 M phosphate buffer solution: (-) $50 \mathrm{mV} \mathrm{s}^{-1},\left(-\right.$ - $\left.^{-}\right) 100 \mathrm{mV} \mathrm{s}^{-1}$ and (...) $300 \mathrm{mV} \mathrm{s}^{-1}$

electrode area in $\mathrm{cm}^{2}, D_{0}$ the diffusion coefficient in $\mathrm{cm}^{2} \mathrm{~s}^{-1}$, $[\mathrm{O}]_{\infty}$ the concentration in $\mathrm{mol} \mathrm{cm}^{-3}$ and $v$ is in $\mathrm{V} \mathrm{s}^{-1}$ [28]. By plotting $I_{\mathrm{pc}}$ versus $v^{1 / 2}$, the $D_{0}$ of isatin was determined from the slope of $-5.05 \times 10^{-6} \mathrm{~A}\left(\mathrm{~V} \mathrm{~s}^{-1}\right)^{-1 / 2}$ to be equal to $4.9 \times 10^{-7} \mathrm{~cm}^{2} \mathrm{~s}^{-1}$ in $\mathrm{pH} 7.00 .2 \mathrm{M}$ phosphate buffer. The GCE electroactive area was calculated to be $0.0310 \mathrm{~cm}^{2}$ using a solution of $0.5 \mathrm{mM}$ hexacyanoferrate $\mathrm{pH} 7.00 .2 \mathrm{M}$ in phosphate buffer, where the diffusion coefficient of hexacyanoferrate is $7.35 \times 10^{-6} \mathrm{~cm}^{2} \mathrm{~s}^{-1}[29]$.

\subsubsection{Differential pulse voltammetry}

The electrochemical reduction of isatin was studied over a wide $\mathrm{pH}$ range between 1 and 13 using DPV. The DP voltammograms (Fig. 7A) were all recorded in solutions of $50 \mu \mathrm{M}$ isatin in different electrolytes with $0.2 \mathrm{M}$ ionic strength. Only peak $3 \mathrm{c}$ occurs in all supporting electrolytes.

The peak $3_{\mathrm{c}}$ potential is displaced to more negative values with increasing $\mathrm{pH}$. The dependence is linear over the whole $\mathrm{pH}$ range from 1 to 9.3 and follows the relationship $E_{\mathrm{pc}}(\mathrm{V})=-0.09-0.059 \mathrm{pH}$ (Fig. 7B). The slope of $57 \mathrm{mV}$ per $\mathrm{pH}$ unit, shows that the same number of electrons and protons is involved in the reduction mechanism of isatin. However, the width at half-height of peak $3_{\mathrm{c}}$ was always $W_{1 / 2}=60 \mathrm{mV}$, which suggests that the reduction of isatin occurs with 2-electron transfer, hence also two protons.
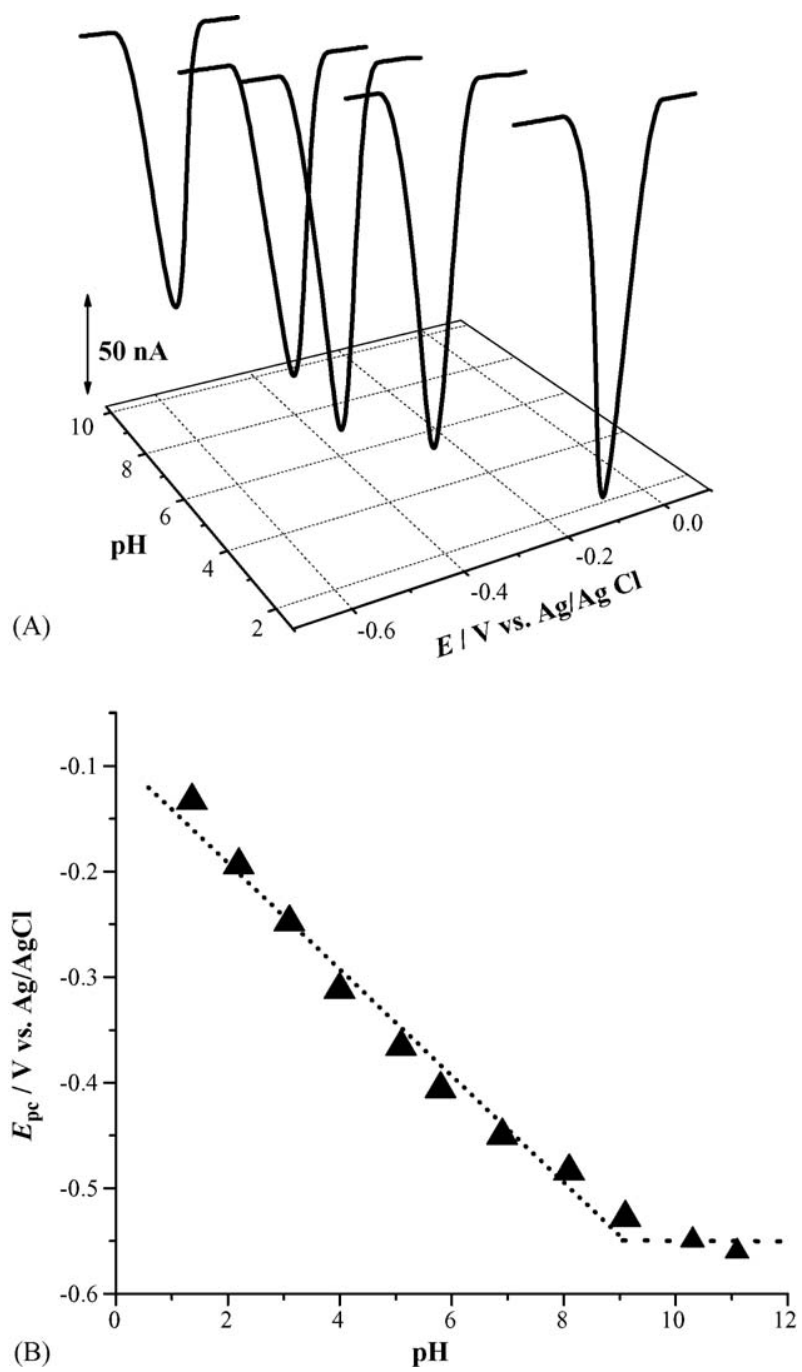

Fig. 7. (A) 3D plot of reduction DP voltammograms obtained in $50 \mu \mathrm{M}$ isatin as a function of $\mathrm{pH}$. (B) Plot of $E_{\mathrm{pc}}$ of peak $3_{\mathrm{c}} \mathrm{vs} . \mathrm{pH}$.

For $\mathrm{pH}>9.3$, the isatin reduction peak $3 \mathrm{c}$ does not depend on $\mathrm{pH}$. The change in the slope was from 57 to $0 \mathrm{mV}$ per $\mathrm{pH}$ unit, indicating a mechanism above $\mathrm{pH} 9.3$ involving only two electrons and no protons, possible if the isatin reduction product undergoes chemical deprotonation in alkaline solutions.

\subsection{Analytical determination of isatin}

Although the procedure for the analytical determination of isatin following the reduction peak $3_{\mathrm{c}}$ is more time-consuming, requiring the deaeration of the solutions, it is preferable since the oxidation of isatin occurs at high potentials and involves complications with the adsorption of isatin oxidation products on the GCE surface.

Two different procedures for the electroanalytical determination of isatin were investigated. DP voltammograms were recorded for standard additions of isatin corresponding to bulk concentrations between 0.2 and $12 \mu \mathrm{M}$ isatin in $\mathrm{N}_{2}$ saturated $\mathrm{pH} 7.00 .2 \mathrm{M}$ phosphate buffer. The detection limit (LOD) was determined as the substance concentration 
that led to a peak with a height three times the baseline noise level. Using the equation $I_{\mathrm{p}}=I_{\mathrm{p}}\left(C_{\text {isatin }}\right)$, the obtained LOD $=3 \times$ S.D. $\times(\text { sensitivity })^{-1}$. The quantification limit (LOQ) is the lowest concentration of a substance that can be quantified with acceptable precision and accuracy. A typical signal/noise ratio of 10 is generally considered to be acceptable; therefore: $\mathrm{LOQ}_{\text {isatin }}=10 \times$ S.D. $\times(\text { sensitivity })^{-1}$.

In the first procedure the electrode surface was polished, between measurements, and conditioned in order to ensure a clean GCE surface. The results obtained for isatin reduction (Fig. 8A and Table 2) show linearity for concentrations of isatin lower than $10 \mu \mathrm{M}$. The high relative standard deviation of $40 \%$ $(n=3)$ was due to the fact that each measurement was done with a freshly polished GCE, a process that led to modifications of the electrode surface.

These analytical data were improved, since neither isatin nor isatin reduction products adsorb on the GCE surface. Thus, in the second procedure, DP voltammograms for isatin reduction were consecutively recorded in solutions of different concentrations of isatin (Fig. 8B). Good linearity was obtained for isatin reduction for concentrations lower than $5 \mu \mathrm{M}$ isatin (Table 2). A relative standard deviation of $3.5 \%(n=3)$ for within-day measurements was obtained.

In order to evaluate the long-term stability of the sensor, one calibration curve was recorded every day and the current for a fixed isatin concentration of $2 \mu \mathrm{M}$ was measured. After 3 days, the sensor showed a decrease of about $9 \%$ with respect to the initial response.

The reproducibility of this method was evaluated by plotting different calibration curves after polishing the GCE surface only at the beginning of each experiment. The results showed a relative standard deviation of $5 \%$ calculated from the sensitivities of three calibration curves.

The results obtained with the electrochemical reduction method were compared with UV-vis studies. Absorption spectra were recorded for bulk concentrations between 1 and $10 \mu \mathrm{M}$ isatin in $\mathrm{pH}$ 7.0 0.2 $\mathrm{M}$ phosphate buffer (Fig. 9). Isatin presents several absorption bands and the calibration curve was obtained by plotting the absorption at $\lambda_{\max }=240 \mathrm{~nm}$ versus isatin concentration, since at this wavelength higher absorbances are obtained. Good linearity was found over the whole concentration range used in this study following the equation:

$$
\begin{aligned}
& A=(0.014 \pm 0.001)+(0.023 \pm 0.004) C, \\
& \left(R^{2}=0.991, \quad \text { S.D. }=0.006, n=27\right)
\end{aligned}
$$

where $A$ is the absorbance in arbitrary units, and $C$ is the isatin concentration in $\mu \mathrm{M}$. However, the detection limit calculated
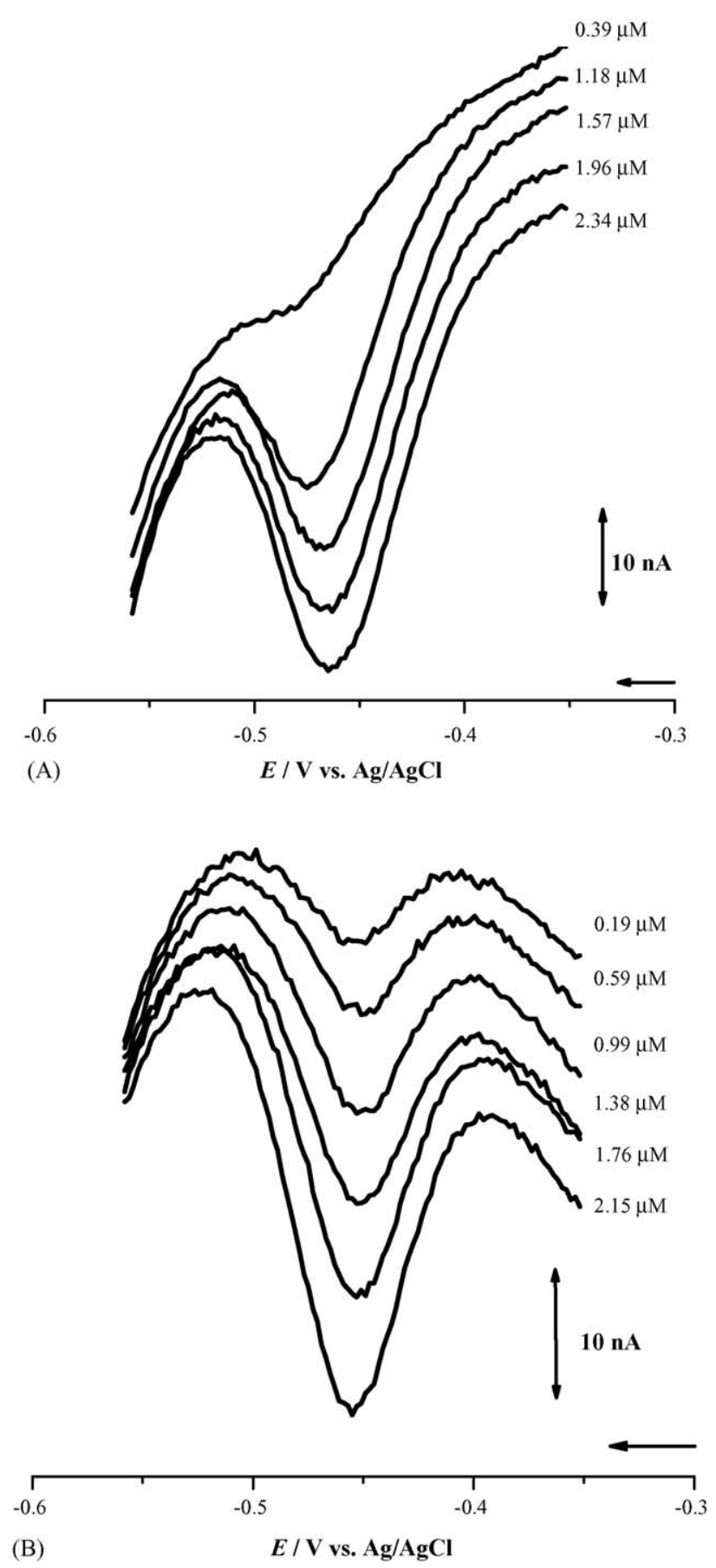

Fig. 8. DP voltammograms in $\mathrm{N}_{2}$ saturated $\mathrm{pH} 7.00 .2 \mathrm{M}$ phosphate buffer in different concentrations of isatin using (A) procedure 1 and (B) procedure 2. For more details see Section 3.3.

Table 2

Sensitivities, intercepts, limits of detection, limits of quantification and other linear fit parameters calculated from isatin calibration curves (see Fig. 8A and B) obtained by two different procedures

\begin{tabular}{lllllllr}
\hline Method & Sensitivity $\left(\mathrm{nA} \mu \mathrm{M}^{-1}\right)$ & Intercept & LOD $(\mu \mathrm{M})$ & LOQ $(\mu \mathrm{M})$ & $R^{2}$ & S.D. & Linearity range $(\mu \mathrm{M})$ \\
\hline Procedure 1 & $11.72 \pm 0.60$ & $1.00 \pm 0.73$ & 0.211 & 0.712 & 0.984 & 0.835 & 10 \\
Procedure 2 & $10.96 \pm 0.24$ & $0.30 \pm 0.35$ & 0.194 & 0.646 & 0.992 & 0.709 & 5 \\
\hline
\end{tabular}

For more details see Section 3.3. 


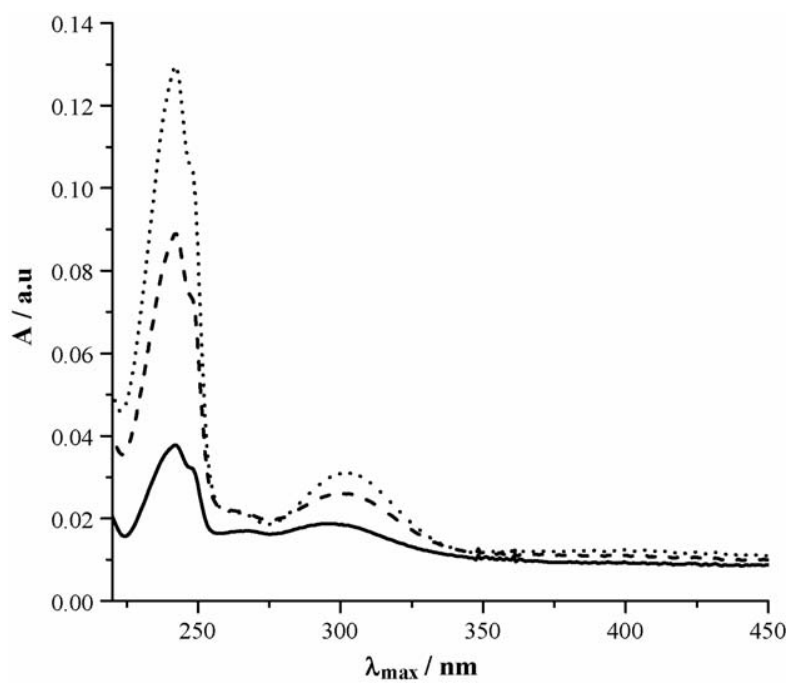

Fig. 9. UV-vis spectra of (-) $1 \mu \mathrm{M},(--) 3 \mu \mathrm{M}$ and (..) $5 \mu \mathrm{M}$ isatin in $\mathrm{pH}$ 7.0 0.2 M phosphate buffer.

with the UV-vis method, LOD $=0.804 \mu \mathrm{M}$, was several times higher than the LOD obtained using the electrochemical reduction method, $\mathrm{LOD}=0.194 \mu \mathrm{M}$.

The electroanalytical method developed for the determination of isatin using the cathodic process is very important because it avoids interferences with many compounds such as glucose or uric, glutamic and ascorbic acids, since all these substances are oxidized at the GCE, besides presenting a lower detection limit than using UV-vis absorption methods.

\section{Conclusions}

This study shows that isatin, a molecule with a broad range of applications in synthetic, biological and clinical activity, undergoes oxidation and reduction at a glassy carbon electrode.

The oxidation of isatin is a $\mathrm{pH}$ dependent, irreversible process and occurs in a single step, with the one electron and one proton transferred, leading to the formation of an electroactive oxidation product that strongly adsorbs on the GCE surface.

The reduction of isatin is also irreversible. Using cyclic voltammetry, two consecutive electron transfer reactions were identified. In electrolytes with $\mathrm{pH}$ less than 9.3 the reduction of isatin follows a mechanism involving the transfer of two electrons and two protons, whereas in more alkaline supporting electrolytes with $\mathrm{pH}>9.3$ the ratio of protons and electrons transferred shifts from 1 to 0 , suggesting a chemical deprotonation of the isatin reduction product.

An electrochemical method was developed for the determination of isatin in $\mathrm{pH} 7.00 .2 \mathrm{M}$ phosphate buffer with $\mathrm{LOD}=0.194 \mu \mathrm{M}$.

\section{Acknowledgements}

Financial support from Fundação para a Ciência e Tecnologia (FCT), Post-Doctoral Grant SFRH/BPD/18824/2004 (V.C. Diculescu), POCTI (cofinanced by the European Community Fund FEDER), and ICEMS (Research Unit 103) is gratefully acknowledged.

\section{References}

[1] P. Rani, V.K. Srivastava, A. Kumar, Eur. J. Med. Chem. 39 (2004) 449.

[2] F. Palluotto, F. Campagna, A. Carotti, M. Ferappi, A. Rosato, C. Vitali, Il Farmaco 57 (2002) 63.

[3] R.N. Goyal, A. Sangal, J. Electroanal. Chem. 578 (2005) 185.

[4] V. Glover, S.K. Bhattacharya, A. Chakrabarti, M. Sandler, Stress Med. 14 (1998) 225.

[5] N. Igosheva, C. Lorz, E. O'Conner, V. Glover, H. Mehmet, Neurochem. Int. 47 (2005) 216.

[6] V. Glover, M.A. Revely, M. Sandler, Biochem. Pharmacol. 29 (1980) 467.

[7] A.E. Medvedev, A. Clow, M. Sandler, V. Glover, Biochem. Pharmacol. 52 (1996) 385.

[8] A.E. Medvedev, O. Bussygyna, N. Pyatakova, N. Glover, I. Severina, Biochem. Pharmacol. 63 (2002) 763.

[9] P. Watkins, A. Clow, V. Glover, J. Halket, A. Przyborowska, M. Sandler, Neurochem. Int. 17 (1990) 321.

[10] A. Medvedev, M. Cromeyrolle-Arias, A. Cardona, M. Sandler, V. Glover, Brain Res. 1024 (2005) 119.

[11] S.K. Bhattacharya, S.B. Acharya, Biogenic Amins 9 (1993) 453.

[12] S.K. Bhattacharya, M. Ramnathan, V. Glover, Biogenic Amins 16 (2000) 63.

[13] E.L. Masden, J.-M. Bollang, Arch. Microbiol. 151 (1989) 71.

[14] A. Medvedev, J. Halket, V. Glover, Med. Sci. Res. 22 (1994) 713.

[15] J.F.M. da Silva, S.J. Garden, A.C. Pinto, J. Braz. Chem. Soc. 12 (2001) 273.

[16] G. Farnia, G. Capobianco, A. Romanin, J. Electroanal. Chem. 45 (1973) 397.

[17] Y. Chi, H. Chen, G. Chen, Anal. Chim. Acta 354 (1997) 365.

[18] M.A. Khattab, M.M. Ghoneim, J. Indian Chem. Soc. LX (1983) 643.

[19] H.P. Agarwal, M. Bhargava, Ind. J. Chem. 12 (1974) 84.

[20] A.M. Oliveira Brett, V.C. Diculescu, J.A.P. Piedade, Bioelectrochemistry 55 (2002) 61.

[21] A.M. Oliveira Brett, J.A.P. Piedade, L.A. da Silva, V.C. Diculescu, Anal. Biochem. 332 (2004) 321.

[22] A.M. Oliveira Brett, F.-M. Matysik, Bioelectrochem. Bioenergy 42 (1997) 111.

[23] R.N. Goyal, N. Kumar, N.K. Singhal, Bioelectrochem. Bioenergy 45 (1998) 47

[24] T. Hu, G. Dryhurst, J. Electroanal. Chem. 362 (1993) 237.

[25] T. Hu, G. Dryhurst, J. Electroanal. Chem. 432 (1997) 7.

[26] J. Osteryoung, R. Osteryoung, Anal. Chem. 57 (1985) 101A.

[27] R.N. Goyal, A. Sangal, Electrochim. Acta 50 (2005) 2135.

[28] C.M.A. Brett, A.M. Oliveira Brett, Electrochemistry. Principles, methods and applications, Oxford University Press, UK, 1993.

[29] http://www.hbcpnetbase.com/; Handbook of Chemistry and Physics. 